\title{
Integrated Nutrient Management in Paddy at Coastal Zone of Karnataka, India
}

\author{
R. Nagaraj $^{1 *}$, M. Hanumanthappa ${ }^{2}$ and K. V. Sudhir Kamath ${ }^{3}$ \\ ${ }^{1}$ (Agronomy), College of Agriculture, UAHS, Shivamogga, Karnataka, India \\ ${ }^{2}$ (Hort.), College of Horticulture, Mudigere, Chickamagluru, Karnataka, India \\ ${ }^{3}$ Department of Agronomy, ZAHRS, Brahmavar, Udupi, Karnataka, India
}

*Corresponding author

\begin{tabular}{|l|}
\hline Ke y w o r d s \\
Yield, Paddy, \\
Vermicompost, \\
Poultry manure, \\
Eupatorium, POP \\
\hline Article Info \\
\hline $\begin{array}{l}\text { Accepted: } \\
\text { 18 May 2018 } \\
\text { Available Online: } \\
\text { 10 June 2018 }\end{array}$ \\
\hline
\end{tabular}

\section{Introduction}

The slogan of "Rice is life" is the staple food for over three billion people of Asia, which accounts for the production and consumption of 90 per cent of world rice. In India rice crop plays vital role in our national food security and is a means of livelihood for millions of rural households. India is the world's second largest producer (129.2 million tonne) of rice

\section{A B S T R A C T}

Significantly higher grain and straw yield $\left(5159 \mathrm{~kg} \mathrm{ha}^{-1}\right)$ of paddy was recorded in package of practice (POP- FYM $5 \mathrm{t}+60: 30: 45 \mathrm{~kg} \mathrm{~N}: \mathrm{P}_{2} \mathrm{O}_{5}: \mathrm{K}_{2} \mathrm{O}$ ha $^{-1}$ ) +50 per cent $\mathrm{N}$ through vermicompost, respectively, followed by $\mathrm{POP}+50$ per cent $\mathrm{N}$ through poultry manure $\left(5101 \mathrm{~kg} \mathrm{ha}^{-1}\right)$ as compared to package of practice (4425 and $5509 \mathrm{~kg} \mathrm{ha}^{-1}$, respectively). Significantly higher total nitrogen and phosphorus uptake was observed in package of practice (POP) +50 per cent $\mathrm{N}$ through vermicompost $\left(109.85\right.$ and $45.51 \mathrm{~kg} \mathrm{ha}^{-1}$, respectively) followed by POP +50 per cent $\mathrm{N}$ through poultry manure (107.96 and 44.92 $\mathrm{kg} \mathrm{ha}^{-1}$, respectively). Total potassium uptake was recorded highest in $\mathrm{POP}+50$ per cent $\mathrm{N}$ through eupatorium $\left(60.23 \mathrm{~kg} \mathrm{ha}^{-1}\right)$, it was followed by POP +50 per cent $\mathrm{N}$ through poultry manure $\left(59.33 \mathrm{~kg} \mathrm{ha}^{-1}\right)$. Maximum available nitrogen $\left(375.90 \mathrm{~kg} \mathrm{ha}^{-1}\right)$ was observed in POP +50 per cent $\mathrm{N}$ through gliricidia followed by $\mathrm{POP}+50$ per cent $\mathrm{N}$ through eupatorium $\left(375.03 \mathrm{~kg} \mathrm{ha}^{-1}\right)$. Available $\mathrm{P}_{2} \mathrm{O}_{5}\left(74.60 \mathrm{~kg} \mathrm{ha}^{-1}\right)$ was more with POP + 50 per cent $\mathrm{N}$ through poultry manure followed by $\mathrm{POP}+50$ per cent $\mathrm{N}$ through goat manure $\left(73.26 \mathrm{~kg} \mathrm{ha}^{-1}\right)$. Application of recommended dose of nutrients i.e. POP (FYM $5 \mathrm{t}$ $+60: 30: 45 \mathrm{~kg} \mathrm{~N}: \mathrm{P}_{2} \mathrm{O}_{5}: \mathrm{K}_{2} \mathrm{O}$ ha $\left.{ }^{-1}\right)+50$ per cent $\mathrm{N}$ through eupatorium and POP +50 per cent $\mathrm{N}$ through vermicompost resulted in higher available $\mathrm{K}_{2} \mathrm{O}\left(135.43\right.$ and $134.13 \mathrm{~kg} \mathrm{ha}^{-1}$, respectively). Significantly higher population of bacteria, fungi and actinomycetes ( 27.27 cfu X $10^{5} \mathrm{~g}^{-1}, 34.86 \mathrm{cfu} \times 10^{3} \mathrm{~g}^{-1}$ and $13.24 \mathrm{cfu} X 10^{4} \mathrm{~g}^{-1}$ of soil, respectively) was found with $\mathrm{POP}+50$ per cent $\mathrm{N}$ through vermicompost. 
largest producer of groundnut (Arachis hypogeal L.). As per Indian Council of Medical Research (ICMR) recommended consumption of $20 \mathrm{~g}$ edible oil/day/person, by 2020 A D, India requires around 20.3 million tonnes of edible oil. To meet this demand, it is essential to enhance the productivity of prominent crops of the country like paddy, wheat, pulses, groundnut through location specific nutrient management practices. To augment major food crops production, Food and Agriculture Organization (FAO) conceptualized the idea of plant nutrients in a crop and cropping system for better resource use. It is not only a reliable way of obtaining fairly higher yields with substantial fertilizer economy, but also a concept that is ecologically sound leading to sustainable agriculture.

The rapid increasing in food production over the past three decades was at the cost of corresponding increase in the removal of nutrient from the soil. The negligence shown to the conservation and use of organic sources of nutrients has not only caused the exhaustion of soil nutrient reserves but also resulted in an imbalance among the available nutrients leading to soil problems. In acidic soils less availability of nutrients $(\mathrm{N}, \mathrm{P}, \mathrm{K}, \mathrm{Ca}, \mathrm{Mg}$ and $\mathrm{S})$ besides inadequate organic matter. Paddy and groundnut are exhaustive crops and removes large amount of macro and micro nutrients from soil. None of the sources of nutrient alone can meet the total plant nutrients from chemical, organic, bio-fertilizer is the most efficient way to supply plant nutrients for sustained crop productivity and improved of soil fertility (Singh and Singh, 2002).

Paddy-legume crop sequence plays a significant role in food security of India. Growing of two crops in a year involves heavy removal of plant nutrients, which diminishes the soil fertility. It is therefore necessary to judiciously manage the inflow of organic sources of nutrients, and their integration with fertilizers, biofertilizers and organic manure. Application of organic materials along with inorganic fertilizers leads to increased productivity of the system and sustained soil health for a longer period (Gawai and Pawar, 2006).

Though many nutrient management studies have been carried out in paddy -legume cropping sequence, the location specific study on integrated nutrient management in rice based cropping sequence (rice-legume) for the farmers of coastal region of Karnataka is lacking. Keeping the above points in view, a field investigation has been carried out to study the effect of supplemental addition of organics along with package of practice through integrated nutrient management in paddy-groundnut cropping sequence at Coastal zone of Karnataka.

\section{Materials and Methods}

A field experiment was conducted during kharif season of 2014 and 2015 at Zonal Agricultural and Horticultural Research Station, Brahmavar, Udupi district, Karnataka, to study the of integrated nutrient management in paddy-groundnut cropping sequence. The experimental site is situated between $74^{0} 45^{\prime}$, to $74^{0} 46^{\prime}$ East longitude and $13^{0} 24^{\prime} 45^{\prime \prime}$ ' to $13^{0} 25^{\prime} 30^{\prime}$ " North latitude and an altitude of 10 meters above mean sea level. Soil type is sandy loam in texture and $\mathrm{pH}$ was acidic (4.62). The soil was medium in available nitrogen $\left(348.70 \mathrm{~kg} \mathrm{ha}^{-1}\right)$, high in available phosphorus (59.10 kg ha-1) and medium in available potassium $\left(106.80 \mathrm{~kg} \mathrm{ha}^{-1}\right)$. The organic carbon content was high $(1.32 \%)$ in range. MO-4 (Red rice) a popular medium duration variety was transplanted in July with a spacing of $20 \mathrm{~cm} \mathrm{X} 10 \mathrm{~cm}$. Experiment included twelve treatments consisted of $\mathrm{T}_{1}-$ Package of practice (POP- FYM $5 \mathrm{t}+$ 
60:30:45 kg N:P $\left.\mathrm{P}_{5}: \mathrm{K}_{2} \mathrm{O} \mathrm{ha}^{-1}\right), \mathrm{T}_{2}-\mathrm{POP}+25$ per cent $\mathrm{N}$ through eupatorium, $\mathrm{T}_{3}-\mathrm{POP}+25$ per cent $\mathrm{N}$ through gliricidia, $\mathrm{T}_{4}-\mathrm{POP}+25$ per cent $\mathrm{N}$ through vermicompost, $\mathrm{T}_{5}-\mathrm{POP}+$ 25 per cent $\mathrm{N}$ through poultry manure, $\mathrm{T}_{6^{-}}$ $\mathrm{POP}+25$ per cent $\mathrm{N}$ through goat manure, $\mathrm{T}_{7^{-}}$ $\mathrm{POP}+50$ per cent $\mathrm{N}$ through eupatorium, $\mathrm{T}_{8}-$ $\mathrm{POP}+50$ per cent $\mathrm{N}$ through gliricidia, $\mathrm{T}_{9^{-}}$ $\mathrm{POP}+50$ per cent $\mathrm{N}$ through vermicompost, $\mathrm{T}_{10^{-}}$POP +50 per cent $\mathrm{N}$ through poultry manure, $\mathrm{T}_{11}-\mathrm{POP}+50$ per cent $\mathrm{N}$ through goat manure and $\mathrm{T}_{12}-$ Control were laid out in Randomized Complete Block Design (RCBD) with three replications. All organics were applied 25 days before transplanting of paddy. Yield (biological and economical) was recorded from individual plots at harvest and converted to $\mathrm{kg} / \mathrm{ha}$. Composite soil sample were used to assess soil nutrient status. Standard statistical methods were used for comparing the treatment means.

\section{Results and Discussion}

\section{Yield attributes of paddy}

Among various INM treatments, average data indicated that significantly higher productive tillers per hill (18.10, 17.68, 16.81 and 16.40), panicle length $(20.19,19.52,19.15$ and 18.63 $\mathrm{cm})$ and panicle weight $(3.96,3.64,3.51$ and $3.47 \mathrm{~g})$ were resulted by the application recommended dose of nutrients $(\mathrm{POP})+50$ per cent $\mathrm{N}$ through vermicompost followed by POP +50 per cent $\mathrm{N}$ through poultry manure and POP +50 per cent $\mathrm{N}$ through eupatorium and goat manure applied treatments $\left(\mathrm{T}_{11}\right.$ and $\mathrm{T}_{7}$ ), respectively. Whereas, test weight was not significantly influenced by the different INM practices. However, it ranged from 22.45 $\mathrm{g}$ in control to $25.48 \mathrm{~g}$ in POP +50 and 25 per cent $\mathrm{N}$ through different organic and green manures treatments (Table 1). Combined application of organic manure with recommended dosage of nutrients showed a significant improvement in different yield attributes which resulted in better yield and economics. The beneficial effect of these attributes seemed to be due to better availability of nutrients and their translocation from source to sink. An improvement in soil microbial activities lead to sympathetic physico-chemical properties which facilitate improved availability and uptake of nitrogen resulted in positive conversion of source to sink escorted to higher panicle length, panicle weight and test weight of rice (Mamta Meena et al., 2013).

\section{Yield of paddy}

Pooled data on grain yield showed that significantly higher grain yield $\left(5159 \mathrm{~kg} \mathrm{ha}^{-1}\right)$ was recorded in POP +50 per cent $\mathrm{N}$ through vermicompost, followed by POP +50 per cent $\mathrm{N}$ through poultry manure (5101 $\mathrm{kg} \mathrm{ha}^{-1}$ ) which was on par with POP +50 per cent through eupatorium $\left(4940 \mathrm{~kg} \mathrm{ha}^{-1}\right)$. The data on straw yield showed that application of recommended dose of nutrients (POP) +50 per cent $\mathrm{N}$ through vermicompost (6679 $\mathrm{kg} \mathrm{ha}^{-1}$ ) followed by POP +50 per cent $\mathrm{N}$ through poultry manure $\left(6562 \mathrm{~kg} \mathrm{ha}^{-1}\right)$ and POP +50 per cent $\mathrm{N}$ through eupatorium (6342 $\mathrm{kg} \mathrm{ha}^{-1}$ ) recorded significantly higher straw yield as compared to rest of the treatments (Table 2). Higher yields with application of vermicompost might be due to increased availability of nutrients, presence of beneficial micro flora such as nitrogen fixers (Lee, 1992) and presence of biologically active metabolites like gibberilins, cytokinins, auxins and group B vitamins (Tomati et al., 1991). The increase in yield owing to the application of poultry manure may be attributed to the fact that poultry manure being important constituents of nucleotides, proteins, chlorophyll and enzymes, involve in various metabolic processes which have direct impact on vegetative and reproductive phases of plants (Rajput et al., 2008). Combined application of inorganic potassium fertilizer 
with $\mathrm{K}$ rich organic manures like, eupatorium and poultry manures are the alternate way to overcome the potassium deficiency rather than the sole application of inorganic $\mathrm{K}$ fertilizer.

The consequences of inadequate $\mathrm{K}$ can be severe for crop growth and efficient utilization of other nutrients such as $\mathrm{N}$ and $\mathrm{P}$. Maintenance of adequate $\mathrm{K}$ is essential for both organic and conventional crop production. Large amounts of $\mathrm{K}$ are required for paddy to maintain plant health and vigor. These results are in agreement with Robert Mikkelsen., 2007.

\section{Uptake of nutrients}

\section{Nitrogen}

Significantly higher total nitrogen uptake was observed in POP +50 per cent $\mathrm{N}$ through vermicompost (109.85 $\mathrm{kg} \mathrm{ha}^{-1}$ ) followed by $\mathrm{POP}+50$ per cent $\mathrm{N}$ through poultry manure and eupatorium applied treatments i.e. $\mathrm{T}_{10}$ and $\mathrm{T}_{7}$ (107.96 and $104.62 \mathrm{~kg} \mathrm{ha}^{-1}$, respectively). Increase in available $\mathrm{N}$ might be attributed to the direct addition of nitrogen through vermicompost and farmyard manure and multiplication of soil microbes, which could convert organically bound $\mathrm{N}$ to inorganic form to the available pool of the soil. Poultry manure contained 60 per cent of $\mathrm{N}$ in the form of uric acid, which changed rapidly to $\mathrm{NH}_{4}^{+}$ form for utilization by rice plants (Prabhakaran, 2000). Chromolaena relatively high $\mathrm{C} / \mathrm{N}$ ratio (12.1) indicates a faster decomposition and also listed high $\mathrm{N}$ content and soluble fraction and moderate lignin content resulting in high biodegradation as the strong point organic matter (Taiwo Agbede and Lawrence Afolabi, 2014).

\section{Phosphorus $\left(\mathrm{P}_{2} \mathrm{O}_{5}\right)$}

Results pertaining to the total uptake of phosphorus at harvest were found significant.
Significantly higher phosphorus uptake (45.51 $\mathrm{kg} \mathrm{ha}^{-1}$ ) was observed in the former treatment $\left(\mathrm{T}_{9}\right)$ followed by POP +50 per cent $\mathrm{N}$ through poultry manure and $\mathrm{POP}+50$ per cent $\mathrm{N}$ through goat manure (44.92 and $45.12 \mathrm{~kg} \mathrm{ha}^{-1}$, respectively). It is evident that the application of organic manure with poultry manure resulted in an increase in available phosphorus content in soil.

The built up of available phosphorus was higher in these organic manures that might be due to release of organic acid during microbial decomposition of organic matter which might have helped in the solubility of native phosphates thus increasing available phosphorus pool in the soil (Stein-Bachinger and Wemer, 2011).

\section{Potassium $\left(\mathrm{K}_{2} \mathrm{O}\right)$}

Recommended nutrient practice $(\mathrm{POP})+50$ per cent $\mathrm{N}$ through eupatorium resulted significantly higher total uptake of potassium $\left(60.23 \mathrm{~kg} \mathrm{ha}^{-1}\right)$, it was followed by POP +50 per cent $\mathrm{N}$ through poultry manure $(59.33 \mathrm{~kg}$ $\left.\mathrm{ha}^{-1}\right)$, POP $+50 \mathrm{~N}$ per cent vermicompost (57.58 kg ha-1) (Table 3). Eupatorium contains higher amount of $\mathrm{K}$, this nutrient in the simple cationic $\mathrm{K}^{+}$form. Most soluble inorganic fertilizers and organic manures are virtually interchangeable as sources of $\mathrm{K}$ for plant nutrition (Li et al., 2006).

\section{Availability of nutrients}

High yield was accompanied by high uptake of nutrients which could be attributed to better availability matching the rhythm of crop growth and high nutrient use efficiency. Improved microbial population in soil under organic condition would have promoted nutrient Maximum available nitrogen (375.90 $\mathrm{kg} \mathrm{ha}^{-1}$ ) was noticed in POP +50 per cent $\mathrm{N}$ through gliricidia followed by POP +50 per cent $\mathrm{N}$ through eupatorium (375.03 $\mathrm{kg} \mathrm{ha}^{-1}$ ). 
Table.1 Yield parameters of paddy as influenced by integrated nutrient management

\begin{tabular}{|c|c|c|c|c|c|c|c|}
\hline & $\begin{array}{l}\text { No. of } \\
\text { productive } \\
\text { tillers hill }^{-1}\end{array}$ & $\begin{array}{c}\text { Panicle } \\
\text { length } \\
\text { (cm) }\end{array}$ & $\begin{array}{c}\text { Panicle } \\
\text { weight } \\
\text { (g) }\end{array}$ & $\begin{array}{l}1000 \text { grain } \\
\text { weight }(g)\end{array}$ & $\begin{array}{c}\text { Grain } \\
\text { yield (kg } \\
\left.\text { ha }^{-1}\right)\end{array}$ & $\begin{array}{c}\text { Straw } \\
\text { yield } \\
\left(\mathrm{kg} \mathrm{ha}^{-1}\right)\end{array}$ & $\begin{array}{l}\text { Harvest } \\
\text { index }\end{array}$ \\
\hline $\mathrm{T}_{1}-$ Package of practice (POP) & 11.65 & 15.84 & 2.27 & 24.33 & 4425 & 5509 & 0.446 \\
\hline $\begin{array}{l}\mathrm{T}_{2}-\mathrm{POP}+25 \% \mathrm{~N} \text { through } \\
\text { eupatorium }\end{array}$ & 12.78 & 16.24 & 3.08 & 23.80 & 4627 & 5719 & 0.447 \\
\hline $\begin{array}{l}\mathrm{T}_{3}-\mathrm{POP}+25 \% \mathrm{~N} \text { through } \\
\text { gliricidia }\end{array}$ & 12.02 & 16.17 & 2.48 & 24.37 & 4468 & 5548 & 0.446 \\
\hline $\mathrm{T}_{4}-\mathrm{POP}+25 \% \mathrm{~N}$ through $\mathrm{VC}$ & 13.96 & 17.04 & 3.23 & 24.17 & 4732 & 5917 & 0.444 \\
\hline $\mathrm{T}_{5}-\mathrm{POP}+25 \% \mathrm{~N}$ through $\mathrm{PM}$ & 13.25 & 16.60 & 3.07 & 24.10 & 4660 & 5803 & 0.445 \\
\hline $\mathrm{T}_{6}-\mathrm{POP}+25 \% \mathrm{~N}$ through $\mathrm{GM}$ & 12.59 & 16.10 & 2.77 & 24.20 & 4551 & 5620 & 0.447 \\
\hline $\begin{array}{l}\mathrm{T}_{7}-\mathrm{POP}+50 \% \mathrm{~N} \text { through } \\
\text { eupatorium }\end{array}$ & 16.40 & 18.63 & 3.47 & 24.61 & 4940 & 6342 & 0.438 \\
\hline $\begin{array}{l}\mathrm{T}_{8}-\mathrm{POP}+50 \% \mathrm{~N} \text { through } \\
\text { gliricidia }\end{array}$ & 15.37 & 18.25 & 3.34 & 25.15 & 4753 & 6174 & 0.435 \\
\hline $\mathrm{T}_{9}-\mathrm{POP}+50 \% \mathrm{~N}$ through $\mathrm{VC}$ & 18.10 & 20.19 & 3.96 & 25.48 & 5159 & 6679 & 0.436 \\
\hline $\mathrm{T}_{10}-\mathrm{POP}+50 \% \mathrm{~N}$ through PM & 17.68 & 19.52 & 3.64 & 25.27 & 5101 & 6562 & 0.438 \\
\hline $\mathrm{T}_{11^{-}} \mathrm{POP}+50 \% \mathrm{~N}$ through $\mathrm{GM}$ & 16.81 & 19.15 & 3.51 & 24.63 & 4865 & 6251 & 0.438 \\
\hline $\mathbf{T}_{12}-$ Control & 7.86 & 11.09 & 1.54 & 22.45 & 2891 & 3521 & 0.450 \\
\hline S. Em \pm & 0.90 & 0.90 & 0.22 & 0.88 & 196 & 293 & 0.015 \\
\hline $\mathrm{CD}(\mathrm{P}=\mathbf{0 . 0 5})$ & 2.64 & 2.64 & 0.65 & NS & 576 & 859 & NS \\
\hline
\end{tabular}

VC- Vermicompost

PM-Poultry manure
GM- Goat manure

POP- FYM 5 t + 60:30:45 kg N:P $\mathrm{O}_{5}: \mathrm{K}_{2} \mathrm{O}$

ha $^{-1}$
25 \& 50\% N through RDN

RDN- Recommended dose of nitrogen

NS- Non significant 
Table.2 Nutrients uptake $\left(\mathrm{kg} \mathrm{ha}^{-1}\right)$ of paddy as influenced by integrated nutrient management

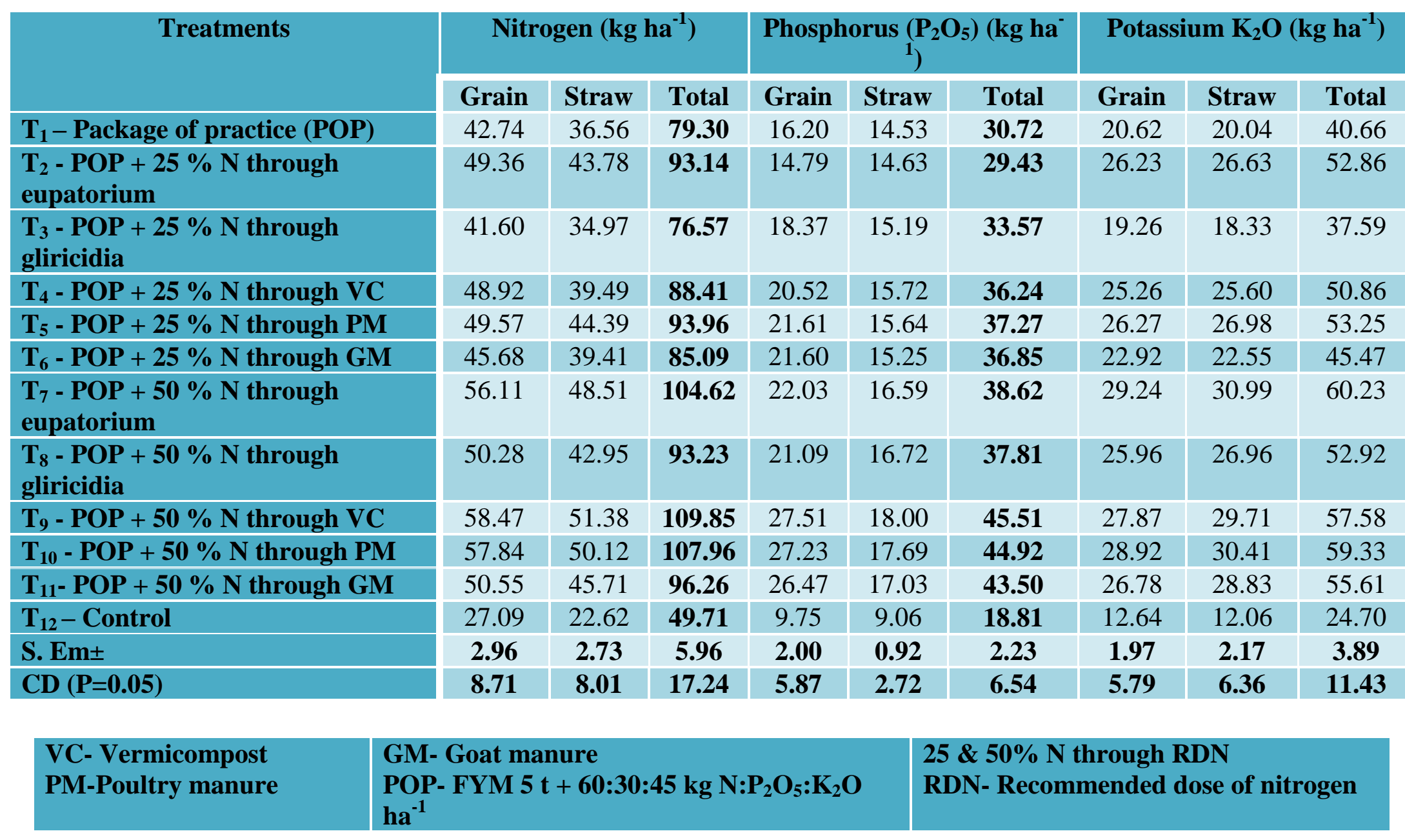


Table.3 Nutrient status of soil and microbial population after harvest of paddy as influenced by integrated nutrient management

\begin{tabular}{|c|c|c|c|c|c|c|}
\hline \multirow[t]{2}{*}{ Treatments } & \multicolumn{3}{|c|}{ Available nutrients ( $\left.\mathrm{kg} \mathrm{ha}^{-1}\right)$} & \multicolumn{3}{|c|}{ Population of soil microorganisms } \\
\hline & $\mathbf{N}$ & $\mathbf{P}_{2} \mathbf{O}_{5}$ & $\mathrm{~K}_{2} \mathrm{O}$ & $\begin{array}{c}\text { Bacteria } \\
\left(\text { cfu } x 10^{5} \mathrm{~g}^{-1}\right. \\
\text { of soil) }\end{array}$ & $\begin{array}{c}\text { Fungi } \\
\left(\text { cfu } \times 10^{3} \mathrm{~g}^{-}\right. \\
\text {of soil) }\end{array}$ & $\begin{array}{c}\text { Actinomycetes } \\
\text { (cfu } \times 10^{4} \mathrm{~g}^{-1} \text { of } \\
\text { soil) }\end{array}$ \\
\hline$T_{1}-$ Package of practice (POP) & 328.73 & 70.48 & 115.96 & 15.55 & 24.12 & 9.10 \\
\hline $\begin{array}{l}\mathrm{T}_{2}-\mathrm{POP}+25 \% \mathrm{~N} \text { through } \\
\text { eupatorium }\end{array}$ & 360.63 & 65.25 & 125.73 & 18.78 & 27.23 & 10.14 \\
\hline $\begin{array}{l}\mathrm{T}_{3}-\mathrm{POP}+25 \% \mathrm{~N} \text { through } \\
\text { gliricidia }\end{array}$ & 359.12 & 71.20 & 121.59 & 17.60 & 26.24 & 9.56 \\
\hline $\mathrm{T}_{4}-\mathrm{POP}+25 \% \mathrm{~N}$ through VC & 362.70 & 70.90 & 123.36 & 18.71 & 29.70 & 10.70 \\
\hline $\mathrm{T}_{5}-\mathrm{POP}+25 \% \mathrm{~N}$ through $\mathrm{PM}$ & 359.10 & 69.40 & 124.38 & 18.07 & 27.90 & 9.58 \\
\hline $\begin{array}{l}\mathrm{T}_{6}-\mathrm{POP}+25 \% \mathrm{~N} \text { through } \\
\text { GM }\end{array}$ & 360.40 & 70.43 & 123.40 & 20.23 & 28.38 & 10.16 \\
\hline $\begin{array}{l}\mathrm{T}_{7}-\mathrm{POP}+50 \% \mathrm{~N} \text { through } \\
\text { eupatorium }\end{array}$ & 375.03 & 60.31 & 135.43 & 22.57 & 30.54 & 11.53 \\
\hline $\begin{array}{l}\mathrm{T}_{8}-\mathrm{POP}+50 \% \mathrm{~N} \text { through } \\
\text { gliricidia }\end{array}$ & 375.90 & 70.37 & 123.97 & 21.30 & 29.10 & 11.07 \\
\hline $\mathrm{T}_{9}-\mathrm{POP}+50 \% \mathrm{~N}$ through VC & 365.30 & 68.10 & 134.13 & 27.27 & 34.86 & 13.24 \\
\hline $\begin{array}{l}\mathrm{T}_{10}-\mathrm{POP}+50 \% \mathrm{~N} \text { through } \\
\mathrm{PM}\end{array}$ & 367.80 & 74.60 & 130.60 & 24.23 & 30.90 & 11.30 \\
\hline $\begin{array}{l}\mathrm{T}_{11}-\mathrm{POP}+50 \% \mathrm{~N} \text { through } \\
\mathrm{GM}\end{array}$ & 370.30 & 73.26 & 128.68 & 26.30 & 33.60 & 12.70 \\
\hline $\mathbf{T}_{12}-$ Control & 312.37 & 45.33 & 80.71 & 8.30 & 13.38 & 6.26 \\
\hline S. Em \pm & 12.31 & 3.49 & 1.77 & 1.77 & 2.11 & 0.74 \\
\hline $\mathrm{CD}(\mathrm{P}=0.05)$ & 36.11 & 10.24 & 5.21 & 5.21 & 6.20 & 2.17 \\
\hline
\end{tabular}

VC- Vermicompost

PM-Poultry manure
GM- Goat manure

POP- FYM $5 \mathrm{t}+60: 30: 45 \mathrm{~kg} \mathrm{~N}: \mathrm{P}_{2} \mathrm{O}_{5}: \mathrm{K}_{2} \mathrm{O}$ ha $^{-1}$
$25 \& 50 \% \mathrm{~N}$ through RDN

RDN- Recommended dose of nitrogen 
Available $\mathrm{P}_{2} \mathrm{O}_{5}\left(74.60 \mathrm{~kg} \mathrm{ha}^{-1}\right)$ was more with $\mathrm{POP}+50$ per cent $\mathrm{N}$ through poultry manure followed by $\mathrm{POP}+50$ per cent $\mathrm{N}$ through goat manure $\left(73.26 \mathrm{~kg} \mathrm{ha}^{-1}\right)$ and POP +25 per cent $\mathrm{N}$ through gliricidia $\left(71.20 \mathrm{~kg} \mathrm{ha}^{-1}\right)$. Application of recommended dose of nutrients (FYM $5 \mathrm{t}+60: 30: 45 \mathrm{~kg} \mathrm{~N}: \mathrm{P}_{2} \mathrm{O}_{5}$ : $\mathrm{K}_{2} \mathrm{O}$ ha $\left.^{-1}\right)+50$ per cent $\mathrm{N}$ through eupatorium resulted in higher available $\mathrm{K}_{2} \mathrm{O}(135.43 \mathrm{~kg}$ $\mathrm{ha}^{-1}$ ) as compared to other treatments (Table 4). Similar observations were resulted by Vadivel et al., (2001) and Rawat and Pareek (2003).

Significantly higher population of bacteria $\left(27.27 \mathrm{cfu} \times 10^{5} \mathrm{~g}^{-1}\right.$ of soil) was found with $\mathrm{POP}+50$ per cent $\mathrm{N}$ through vermicompost followed by POP +50 per cent $\mathrm{N}$ through goat manure (26.30) and $\mathrm{POP}+50$ per cent $\mathrm{N}$ through poultry manure (24.23). Significantly higher population of fungi was found with $\mathrm{POP}+50$ per cent $\mathrm{N}$ through vermicompost and $\mathrm{POP}+50$ per cent $\mathrm{N}$ through goat manure (34.86 \& $33.60 \mathrm{cfu} \times 10^{3} \mathrm{~g}^{-1}$ of soil, respectively) that on par with $\mathrm{POP}+50$ per cent $\mathrm{N}$ through poultry manure (30.90). Recommended practice +50 per cent $\mathrm{N}$ through vermicompost, $\mathrm{POP}+50$ per cent $\mathrm{N}$ through goat manure and $\mathrm{POP}+50$ per cent $\mathrm{N}$ through eupatorium produced significantly higher population of actinomycetes (13.24, 12.70 and $11.53 \mathrm{cfu} \times 10^{4} \mathrm{~g}^{-1}$ of soil, respectively) as compared to other treatments. These results are in conformity with findings of Badole and More (2001) who reported that application of FYM $25 \mathrm{t} \mathrm{ha}^{-1}$ recorded higher population of Rhizobium, Azatobacter, fungi, actinomycetes, PSB and bacteria $\left(10.5 \times 10^{3}\right.$, $0.38 \times 10^{3}, 6.7 \times 10^{3}, 14.9 \times 10^{4}, 29.1 \times 10^{4}$ and $62.5 \times 10^{4}$ cells $\mathrm{g}^{-1}$ soil, respectively) as compared to control treatment.

\section{References}

Badole, S.B. and More, S.D., 2001. Residual effect of nutrient management on yield of groundnut. J. Maharashtra Agric. Univ., 26(1): 109-110.

Lee, K.E., 1992, Some trends and opportunities in earthworm research. Soil Biology and Biochemistry. 24: 1765-1771.

Li, X.F., Singh, B. and Rengel, Z. 2006, Decomposition of maize straw in saline soil. Biol. Fertil. Soils. 42:366-370.

Prabhakaran, C. 2000. Studies on organic farming in tomato. M.Sc., (Ag.) Thesis, Tamil Nadu Agric. Univ., Vallanad.

Rajput, M.K.K., Ansari, A.H., Mehdi, S. and Hussain, A.M., 2008. Effect of $\mathrm{N}$ and $\mathrm{P}$ fertilizers alone and in combination with OM on the growth and yield of wheat. Sarhad J. Agri. Res. 4: 3-6.

Rawat, S.S. and Pareek, R.G., 2003. Effect of FYM and NPK on yield and nutrient uptake for soil fertility in wheat. Annals of Ari-Bio-Research. 8(1): 17-19.

Robert L. Mikkelsen., 2007. Managing potassium for organic crop production. Hortechnology, 17(4): 455-460.

Stein-Bachinger, K and Wemer, W., 2011. Effect of manure on crop yield and quality in an organic agricultural system. Biological Agriculture and Horticulture. 14: 221-235.

Taiwo M. Agbede and Lawrence a. Afolabi, 2014. Soil fertility improvement potentials of Mexican sunflower (Tithonia diversifolia) and Siam weed (Chromolaena odorata) using okra as test crop. Archives of Applied Science Research. 6 (2): 42-47.

Tomati, U., Grappelli, A., Galli, E and Rossi, W., 1991. Fertilizers from Vermiculture as an option for organic waste recovery. Agrochimica. 27:244-251.

Vadivel, N., Subbian, P. and Velayutham, A., 2001. Effect of integrated nutrient management practices on the growth and yield of rainfed winter maize (Zea mays). Indian Journal of Agronomy, 46(2): 250-254. 
How to cite this article:

Nagaraj R., M. Hanumanthappa and Sudhir Kamath K. V. 2018. Integrated Nutrient Management in Paddy at Coastal Zone of Karnataka. Int.J.Curr.Microbiol.App.Sci. 7(06): 1745-1753. doi: https://doi.org/10.20546/ijcmas.2018.706.207 